\title{
Information and Communication Technologies as a competitive performance factor in provider institutions of medical services in Ensenada, Baja California
}

Tecnologías de la Información y la Comunicación como factor de desempeño competitivo en las instituciones prestadoras de servicios médicos en Ensenada, Baja California

\author{
José Felipe Ramírez-Pérez ${ }^{a}$, Virginia Guadalupe López-Torres ${ }^{b}$, Maylevis Morejón-Valdés ${ }^{c}$
}

\begin{abstract}
:
At present, the effects of competitiveness have transcended the business environment and have become essential aspects in organizations. The health sector has not been exempt from this phenomenon, which is essential to achieve greater hospital efficiency. In this context, the use of information and communication technologies has become a new factor of competitive advantages. The objective of the research is to demonstrate that information and communication technologies constitute a competitive performance factor in health institutions, for the achievement of competitive advantages. The research has a qualitative approach, with a descriptive scope, of a retrospective type and a non-experimental, cross-sectional design. A meta-analysis was carried out, guided by a procedure for its execution. As a result, it was determined that the use of information and communication technologies, from its technological, management and social impact dimensions, constitutes a competitive performance factor in health, from its dimension of control of material resources, quality of healthcare process and patient care time. As a conclusion, it is affirmed that their use in health institutions in Ensenada, Baja California, can contribute to the achievement of competitive advantages and greater hospital efficiency.
\end{abstract}

Keywords:

Competitiveness, competitive performance, health institutions, hospital efficiency, information and communication technology.

\section{Resumen:}

En la actualidad, los efectos de la competitividad han trascendido del entorno empresarial y se han convertido en aspectos imprescindibles en las organizaciones. El sector de la salud no ha estado exento de este fenómeno, imprescindible para lograr una mayor eficiencia hospitalaria. En este contexto, el empleo de las tecnologías de la información y la comunicación han devenido en un factor novedoso de ventajas competitivas. El objetivo de la investigación es demostrar que las tecnologías de la información y la comunicación constituyen un factor de desempeño competitivo en las instituciones de salud, para el logro de ventajas competitivas. La investigación tiene un enfoque cualitativo, con alcance descriptivo, de tipo retrospectivo y diseño no experimental, de corte transversal. Se llevó a cabo un meta-análisis, guiado por un procedimiento para su ejecución. Como resultado se determina que el empleo de las tecnologías de la información y la comunicación, desde su dimensión tecnológica, de gestión e impacto social, constituye un factor de desempeño competitivo en salud, desde su dimensión tiempo de atención a pacientes, control de recursos materiales y calidad del proceso de atención. Como conclusión, se afirma que su empleo en las instituciones de salud en Ensenada, Baja California, puede contribuir al logro de ventajas competitivas y una mayor eficiencia hospitalaria.

\section{Palabras Clave:}

Competitividad, desempeño competitivo, eficiencia hospitalaria, instituciones de salud, tecnología de la información y la comunicación.

\footnotetext{
Corresponding author, Faculty of Administrative and Social Sciences. Autonomous University of Baja California. Ensenada, Baja California, México. https://orcid.org/0000-0002-0765-0685, Email: jramirez14@uabc.edu.mx

b Faculty of Administrative and Social Sciences. Autonomous University of Baja California. Ensenada, Baja California, México. https://orcid.org/0000-0002-2795-8951, Email: virginia.lopez@uabc.edu.mx

Faculty of Administrative and Social Sciences. Autonomous University of Baja California. Ensenada, Baja California, México.
} https://orcid.org/0000-0002-5831-9159, Email: maylevis.morejon@uabc.edu.mx 


\section{Introducción}

Over the years, the effects of competitiveness have transcended the business environment, have positioned themselves and have become essential aspects in all activities of governments and health ministries. Likewise, they have come to have a direct impact on people, organizations and institutions where efficiency, effectiveness, resource savings, quality of services, performance and productivity are strategic objectives [1].

The health sector has not been exempt from this phenomenon of competitiveness and the need for greater hospital efficiency, although it has been shown that there are not enough research, case reports or books that address this phenomenon in the health field and the hospital sector specifically [2-4]. In the region of Baja California, the impact scientific literature consulted is also scarce in the treatment of this topic, as stated by several researchers.

At present, the hospital institution can be considered a competitive organization, being a basic institutional agent of all health system and a multi-service organization of great complexity. In it converges the need to ensure the quality of services provided, the effectiveness and efficiency of the hospital, with the management of knowledge, competence and performance of the human factor [5-7].

In this interdisciplinary and multifactorial context, technological innovation and with it the use of information and communication technologies (ICT) have become a novel factor for the achievement of superior results or competitive advantages in themselves [8-10]. Authors such as Vasco, Weng, Giacometti-Rojas and collaborators refer to technological innovation constitutes a key factor to achieve sustained levels of competitiveness. In the health sector, its use impacts on the elevation of competitive performance and hospital efficiency, such are the cases of the processes of care, diagnosis and treatment of diseases [6,11-13].

Competitive health performance is defined as the ability of a hospital to develop a superior performance, which allows it to be in a position of competitive advantage, compared to other hospitals [12]. Likewise, ICT are defined as the set of technologies that currently exist (hardware and software) to enable the more efficient creation, use, storage, processing, distribution and communication of data and information $[14,15,16]$.

The objective of the research is to demonstrate that ICT constitute a competitive performance factor in provider institutions of medical services, which if used in hospitals in Ensenada, Baja California, can contribute to the achievement of competitive advantages and better hospital performance.

\section{Literature review}

The discussion between technology, competitiveness and production has been widely approached in the business field, but not in the health sector, where these terms have been more linked to sector reforms, introduction of market instruments and management competition. All of this has generated a greater concern about performance and sustainability in health sector organizations [6].

Following a historical-logical approach, a scientific review is carried out in primary sources, published in high-impact databases, of relevant authors on the subject. In their manuscripts, ICT are addressed as a competitive performance factor of health institutions:

- Vasco and collaborators present a conceptual framework that, with the use of ICT, could evaluate hospital competitiveness, which would allow to improve its operation, optimization of processes and use of resources [12].

- Weng and collaborators refer that technological innovation really affects hospital performance, favoring timely medical-administrative decision making. In the research, they also exemplify that their positive results are reflected in emergency, outpatient and hospitalization services [13].

- Giacometti-Rojas in his research confirms that technological innovation is a key factor in maintaining competitiveness. In health, its use impacts on the elevation of competitive performance, such are the cases of the processes of care, diagnosis and treatment of diseases [6].

- Likewise, Pérez and collaborators carry out an economic feasibility analysis, where it is demonstrated how the use of ICT the costs of medical care are reduced, allowing a greater control and traceability of processes, to contribute to a medical care improvement [16].

- Álvarez-Tobón and collaborators address that ICT offer mechanisms to increase the effectiveness and efficiency of medical care. In addition, by continuously monitoring the information generated, care costs and patient waiting times can be reduced. All of this increase the quality of medical care and satisfaction with medical processes [17].

- According to Jiang and collaborators, the use of ICT is a novel tool to improve the impact of healthcare. It allows a more equitable and efficient access to services and improves the quality-cost-effectiveness trinomial of treatments [18].

- Finally, Wu and Trigo propose that the use of ICT improves care and administrative processes in various health institutions. In addition, they have a high social impact to reduce medical errors [19]. 


\section{Methods}

The work focuses on demonstrating that ICT constitutes a competitive performance factor in provider institutions of medical services. The research was based on the consultation of books and scientific articles published in high-impact indexed journals. In Ensenada, Baja California their use can contribute to the achievement of greater competitive advantages in their hospitals, as well as to a better operation and efficiency of the same.

The research has a qualitative approach, with a descriptive scope, retrospective type and a non-experimental, crosssectional design. A meta-analysis was performed, as a summary mechanism of multiple studies related to a specific issue, which follows the procedure established by Gurevitch and collaborators, where it must be [20]:

1. Determine the quality of studies that include it.

2. Take into account the bias itself publication, the results obtained being significant.

3. Take into account the articles selection bias, including representative studies of phenomenon under study.

4. Take into account variability or heterogeneity of studies.

5. Achieve a correct interpretation of results obtained.

A meta-analysis was carried out in the period from January 2020 to August 2020, where the bibliography analyzed was essentially comprised in the period from 2015 to 2020 (92\%), of which $84 \%$ is in English language. The search was carried out in high-impact scientific journals indexed in databases such as Web of Sciences, Scopus, Ebsco and Scielo, and publishers such as Elsevier, IEEE, ACM and Springer.

The following descriptors were used for its realization: competitiveness, competitive performance, hospital efficiency, health institutions and Information and Communication Technologies. The main scientific methods applied were documentary analysis, historicallogical and analysis-synthesis method. 129 scientific documents of interest, associated with ICT, competitive performance, health institutions and Baja California were analyzed.

According to Vasco and collaborators [12], hospital competitiveness is defined as the capacity of a hospital to develop a superior performance, which allows it to be in a position of competitive advantage, compared to other hospitals. In addition, the authors state that this superior competitive performance can be analyzed from several dimensions at a macro level, among which they mention the organizational dimension, the strategic behavior dimension and the performance dimension, as shown in Figure 1.

The conceptualization of each of these dimensions is based on debates of the classic authors in the field of strategic management. Performance is also included as an essential dimension to analyze competitiveness.

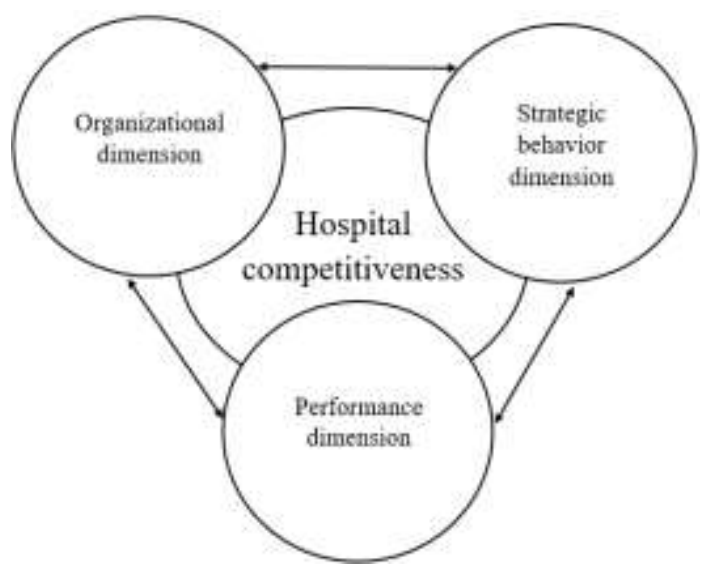

Figure 1. Dimensions of hospital competitiveness. Source: own elaboration with data obtained from [12; p. 441].

Vasco and collaborators developed a conceptual framework to analyze hospital competitiveness [12]. To each one of the dimensions shown in Figure 1, indicators or microscope dimensions are added, which allow to measure hospital competitiveness, as shown in Figure 2. Taking into account such research, it is used as a scientific basis to support the selection of the dimensions to be analyzed, as part of the competitive performance variable. This analysis is performed and evidenced in Figure 3.

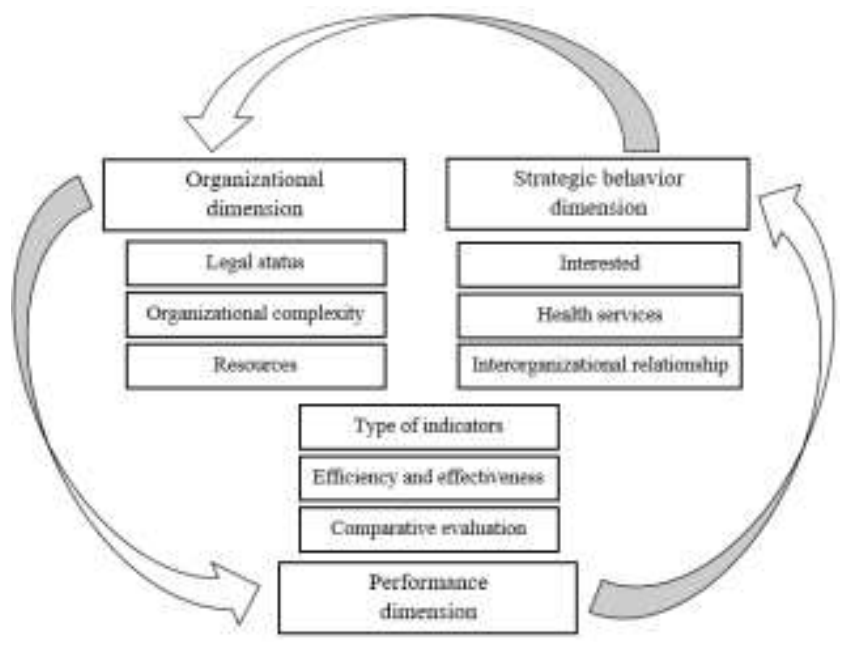

Figure 2. Indicators for each dimension of hospital competitiveness. Source: own elaboration with data obtained from [12; p. 441].

\section{Results and discussion}

As results of the research process, it is obtained that the use of ICT, from its technological, management and social impact dimensions, constitutes a competitive performance factor in health, from its dimension of control of material resources, quality of healthcare process and patient care time. As illustrated below, the authors determined a relation between the variables to infer that: the use of ICT constitutes a competitive performance factor in provider institutions of medical services. The above statement 
makes it possible to determine that their employment in hospital institutions in Ensenada, Baja California, can contribute to the achievement of competitive advantages and better hospital efficiency.

In Figure 3 shown below, the relation of each of the ICT dimensions is established, as well as the competitive performance dimensions, which impact hospital institutions. In addition, the main authors who have addressed it and have contextualized it to the health sector are associated with each variable or dimension.

Next, the main results obtained and the most important
The management dimension refers to how ICT are used to support timely decision-making by the medicaladministrative staff on the control of material resources used. In this way, you can make better use and saving of this type of resources. Although ICT are an impact factor for administrators, in their role of control and timely decision making, the use of ICT in health administration is a field still to be developed in much greater depth [25].

In the field study conducted by Shafaghat and collaborators, a positive relationship was found between the use of technology and a superior performance, given
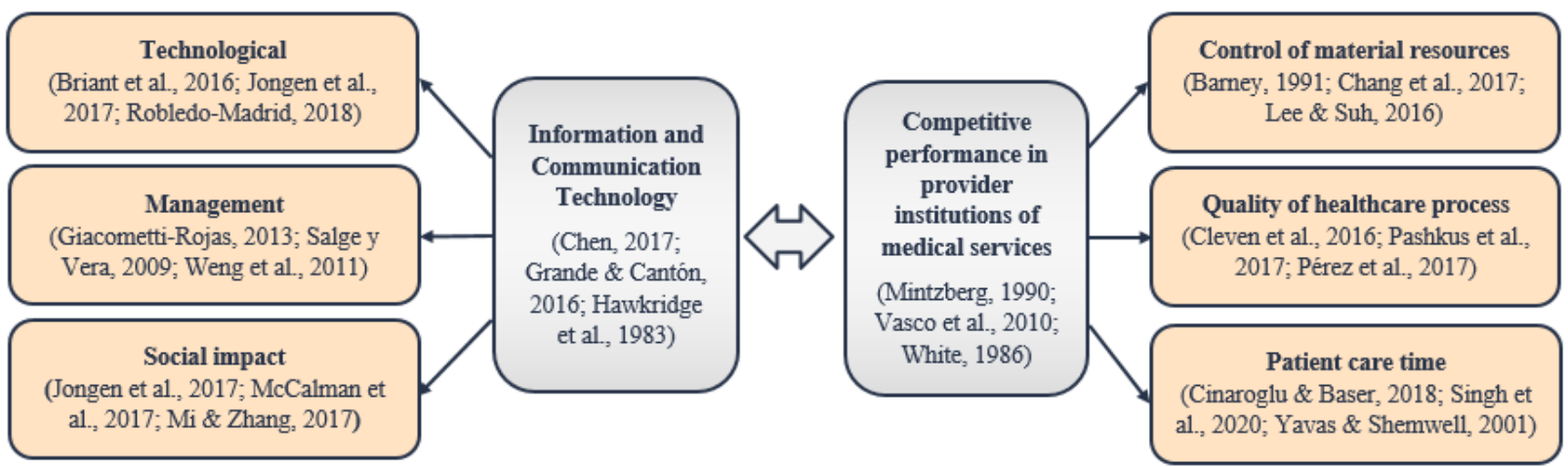

Figura 3. ICT as a competitive performance factor in provider institutions of medical services in Ensenada, Baja California. Source: own elaboration.

statements of the authors are addressed, regarding how ICT impact on the competitive performance in provider institutions of medical services from the technological, management and social impact dimensions:

\section{- Technological:}

Technological dimension, as part of the use of ICT, is basic but not redundant. This is because it aims to evaluate how the use of information technologies in the medical care favors the efficiency in medical processes, contributing to the reduction of care times. It can be seen specifically in the implementation of electronic health records, which contributes to the processes of registration, admission, consultation care and obtaining drugs in the pharmacy, just to cite several examples [21,22]. The previous case is used in contrast to hospitals in which no automated processes are performed.

In the work developed by Wu and Trigo, the authors state that the use of electronic supports in the patient care process is beneficial and has been subject of numerous researches [19]. It favors the reduction of errors in medical prescription and adherence to clinical practices, which improves medical care processes, reducing attention times [23,24].

\section{- Management:}

by an effective control and use of resources [4]. In hospital institutions, administrators have a high interest in applying ICT in order to improve hospital efficiency and effectiveness. It has been evidenced that its use in hospitals shows superior performance, in the control of resources and their effective use $[6,13,26]$.

\section{- Social impact:}

Social dimension of ICT refers to how its use can be a tool to assess the perceived quality of the care process by patients, as a third party service. Likewise, there are highimpact studies consulted that confirm the use of ICT for this purpose, and how it constitutes an excellent way to obtain competitive advantages by health units, continuously improving their work, being a reference for the population.

ICT are a strategic tool for organizational development. They raise quality standards, through social inclusion. They have a positive impact on the well-being of patients, by favoring communication in the care process [24,27,28]. In Figure 4 a summary of the information obtained is shown, where ICT are conceptualized, which led to determine the dimensions to study and relationate, as well as the conceptualization and impact that each of these dimensions has. 

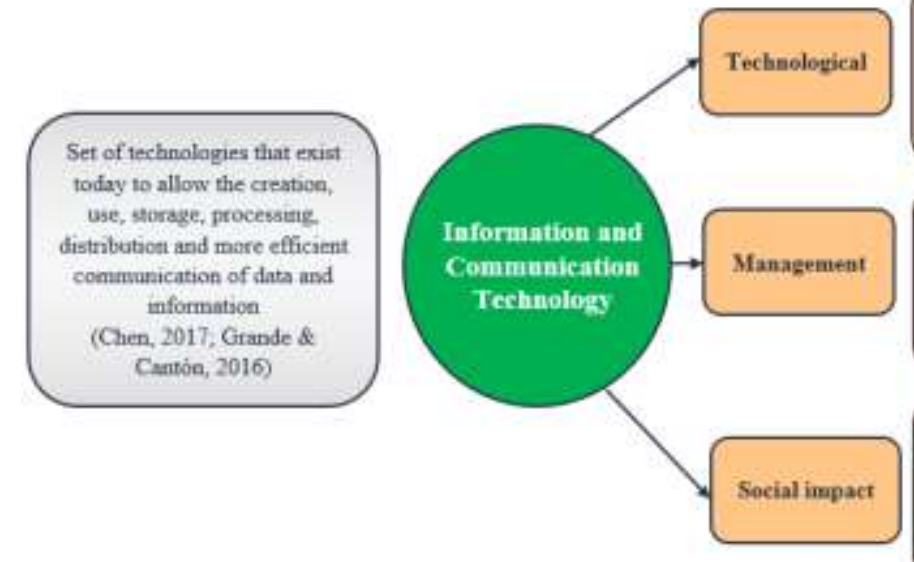

The asc of ICT in the patient care process is beneficial in favors the reduction of errors in prescription and asherence to clinical practices, which improves medical care processes, reducing attention times (Briant et al , 2016 Jobyen et al, 2017; Robledo-Madrid, 2018

In hospital instintions administratons bave a high degree of applying ICT to ineprove efficiency and effectiveness. It has been evidenced that its use in hospitals shows superior performmoc, boch in the control of resources and in therr effective use (Giacometti-Rojas, 2013: Wene et al, 2011)

It is a strategic tool for ortyanizational development Raises quality standauds, through social inclusion. It has a positve impact on the well-being of patients, by promoting communication in the care process (Jongen et al, 2017, Lucivero \& Jongama, 2018: McCalman et al, 2017, Mi \& Zhang, 2017)

Figure 4. Relation between ICT and proposed dimensions. Source: own elaboration.

Next, the researches consulted are addressed that testify that a timely control of material resources, a higher quality of healthcare process and the decrease in patient care times, constitute dimensions for a better competitive performance in health institutions:

\section{- Control of material resources:}

According to Vasco and collaborators, supported by authors who have dealt with the vision of the company's resources, a hospital can consider a set of heterogeneous resources with attributes, which contributes to a sustained competitive advantage [12].

It constitutes a competitive performance factor and hospital efficiency, because its use and structure, as well as the timely control influence the economic behavior of health organizations [29]. In addition, the way in which resources are structured within an organizational unit influences the strategies adopted by the institutions, in their desire to achieve competitive advantages that allow them to obtain superior returns in their organic functioning [30].

\section{- Quality of healthcare process:}

In accordance with Syed, Stefan and collaborators, the quality of health services and within it, the quality of medical care process itself, is an essential aspect to achieve a superior competitive performance, since it generates advantages [31,32]. This is due to the fact that a superior quality in medical care sometimes does not mean a higher cost in the medical care process, instead, it allows to improve the services provided, to refine them, to minimize and control expenses, as part of the process, a conclusion that Pérez and collaborators also reach in their research [16].

The quality of the medical care process is related to hospital efficacy and efficiency $[4,33,34]$, because:
> Higher quality allows to improve services and minimize expenses, contributing to health institutions efficiency.

$>$ Hospital efficiency lies in the ability to provide highquality medical care.

The study carry out by Pashkus and collaborators showed that a significant part of medical errors (between 22 and $28 \%$ ) is due to a low quality in the medical care process [34].

\section{- Patient care time:}

Competitive advantage is shown when better performance indicators are evidenced, in a lasting and sustained way compared to other hospitals. To this end, it is essential to generate sustained levels of performance, as a result of the high efficiency and effectiveness of its substantive processes. A visible element in this is the time of medical care, which also shows a superior quality in the care process [35,36].

Furthermore, according to the research carried out by Zuriati, Chiew, Moreira and collaborators, in an increasingly competitive hospital environment with firstclass services, one of the factors why patients choose some hospitals over others is precisely the total time of the care process and its quality. This shows, therefore, a highly important factor for obtaining competitive advantages [37,38].

Likewise, Figure 5 shows a summary of the information obtained, where competitive performance in hospital institutions is conceptualized and contextualized, which favors the determination of the dimensions to be studied and related, as well as the conceptualization and impact that each one of these dimensions has in health. 


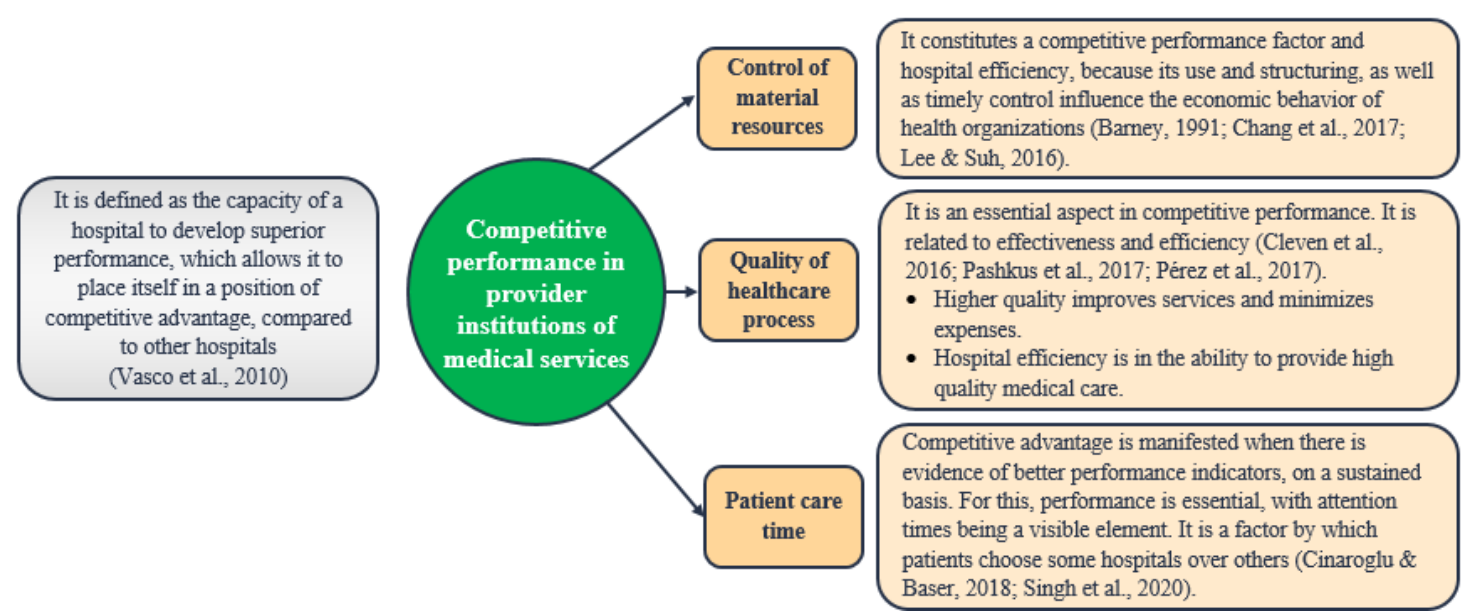

Figure 5. Relation between competitive performance and proposed dimensions. Source: own elaboration.

\section{Conclusions}

In health sector worldwide, today it is a priority to increase the competitive performance in provider institutions of medical services. This requirement aims to reduce costs and increase productivity, in a context where the accelerated aging of the population and the increase in chronic diseases is increasingly latent. That is why researches such as the one presented, with a solution from innovation, has an impact on a higher quality of life for the population and an improvement in health coverage.

Dissimilar researches showed that ICT offer approaches and tools to increase the performance, effectiveness and efficiency of medical care. Likewise, its impact in competitive performance and achievement of competitive advantages was verified. In addition to the continuous monitoring of the information generated and the resources used, waiting and care times can be reduced and the quality of medical care offered can be increased.

In this sense, the research confirms that the use of ICT, from its technological, management and social impact dimension, constitutes a competitive performance factor in health, from its dimension of control of material resources, quality of healthcare process and patient care time. All of the above indicates that its use in hospital institutions in Ensenada, Baja California, can contribute to the achievement of competitive advantages, better operation and greater hospital efficiency.

\section{Referencias}

[1] González Rosales, V. M., López Torres, V. G., \& Meraz Ruiz, L. (2019). Tourism competitiveness, analysis of validity and factorial, San Felipe, Baja California case. Economía Sociedad y Territorio, 19(61), 305-338.

[2] Barba-Sánchez, V., Calderón-Milán, M. J., \& Atienza-Sahuquillo, C. (2018). A study of the value of ICT in improving corporate performance: a corporate competitiveness view. Technological and Economic Development of Economy, 24(4), 1388-1407.

[3] Ramírez Pérez, J. F., Estrada Sentí, V., Morejón Valdés, M., \& Arza Pérez, L. (2017). Modelo para la gestión y análisis de conocimiento para la selección de equipos de trabajo quirúrgico en sistemas de información en salud mediante técnicas de inteligencia organizacional. Revista cubana de información en ciencias de la salud, 28(1), 43-60.

[4] Shafaghat, T., Rahimi Zarchi, M. K., Hatam, N., \& Kavosi, Z. (2020). Determining and Ranking of Indicators for Efficiency Evaluation of Hospitals. Journal of Health Management \& Informatics, 7(1), 10-16.

[5] Davlyatov, G., Borkowski, N., Feldman, S., Qu, H., Burke, D., Bronstein, J., \& Brickman, A. (2019). Health Information Technology Adoption and Clinical Performance in Federally Qualified Health Centers. Journal for healthcare quality. Official publication of the National Association for Healthcare Quality. DOI: 10.1097/JHQ.0000000000000231

[6] Giacometti-Rojas, L. F. (2013). Innovación tecnológica y desarrollo de ventaja competitiva en la atención a la salud: enfoque conceptual y metodológico. Gerencia y Políticas de Salud, 12(25).

[7] Valdés, M. M., Pérez, J. F. R., Fuentes, A. P., \& Pérez, A. D. R. R. (2020). Strategy to Implant the System XAVIA HIS in Hospital Institutions. Revista Cubana de Informática Médica, 12(1), 3-19.

[8] Agwunobi, A., \& Osborne, P. (2016). Dynamic capabilities and healthcare: a framework for enhancing the competitive advantage of hospitals. California Management Review, 58(4), 141-161.

[9] Ariani, A., Koesoema, A. P., \& Soegijoko, S. (2017). Innovative healthcare applications of ICT for developing countries. In Innovative Healthcare Systems for the 21st Century (pp. 15-70). Springer, Cham.

[10] Valencia-Moreno, J. M., López, E. G., Pérez, J. F. R., Rodríguez, J. P. F., \& Xochihua, O. Á. (2020). Exploring Breast Cancer Prediction for Cuban Women. In International Conference on Information Technology \& Systems (pp. 480-489). Springer, Cham.

[11] Jacquez-Hernández, M. V., \& Torres, V. G. L. (2018). Modelos de evaluación de la madurez y preparación hacia la Industria 4.0: una revisión de literatura. Ingeniería Industrial. Actualidad y Nuevas Tendencias, 6(20), 61-78.

[12] Vasco, E., Barbosa, N., \& Figueiredo, J. (2010). A conceptual framework to analyze hospital competitiveness. The Service Industries Journal, 30(3).

[13] Weng, R. H., Huang, J. A., Kuo, Y. H., Huang, C. Y., \& Huang, Y. C. (2011). Determinants of technological innovation and its effect on hospital performance. African Journal of Business Management, 5(11), 4314-4327.

[14] Calvo, F., Carbonell, X., \& Johnsen, S. (2019). Information and communication technologies, e-Health and homelessness: A bibliometric review. Cogent Psychology, 6(1), 1631583.

[15] Jones, P., Wynn, M., Hillier, D., \& Comfort, D. (2017). The sustainable development goals and information and communication technologies. Indonesian Journal of Sustainability Accounting and Management, 1(1), 1-15. 
[16] Pérez, J. F. R., Valdés, M. M., \& Sentí, V. E. (2017). Modelo computacional experto para la recomendación de equipos de trabajo quirúrgico en sistemas de información en salud aplicando técnicas de análisis de redes sociales y minería de procesos. XIII Congreso Interamericano de Computación Aplicada a la Industria de Procesos. Instituto Tecnológico Autónomo de México (ITAM). Disponible en: http://www.caip2017.itam.mx/files/libroResumenes.pdf?

[17] Álvarez-Tobón, V. A., Luna-Gómez, I. F., Torres-Silva, E. A., Higuita-Úsuga, A., \& Rivera-Mejía, P. T. (2018). Tecnologías de Información y Comunicación (TIC) aplicadas en cuidados paliativos: revisión de tema. Psicooncología, 15(2), 345.

[18] Jiang, X., Ming, W. K., \& You, J. H. (2019). The cost-effectiveness of digital health interventions on the management of cardiovascular diseases: systematic review. Journal of medical Internet research, 21(6), e13166.

[19] Wu, Z., \& Trigo, V. (2020). Impact of information system integration on the healthcare management and medical services. International Journal of Healthcare Management, 1-9.

[20] Gurevitch, J., Koricheva, J., Nakagawa, S., \& Stewart, G. (2018). Meta-analysis and the science of research synthesis. Nature, 555(7695), 175-182.

[21] Chang, C. H., Chiao, Y. C., \& Tsai, Y. (2017). Identifying competitive strategies to improve the performance of hospitals in a competitive environment. BMC health services research, 17(1), 756.

[22] Mayer, T., \& Jensen, K. (2018). Hardwiring hospital-wide flow to drive sustainable competitive performance. Management in Healthcare, 2(4), 373-387.

[23] Briant, K. J., Halter, A., Marchello, N., Escareño, M., \& Thompson, B. (2016). The power of digital storytelling as a culturally relevant health promotion tool. Health promotion practice, 17(6), 793-801.

[24] Jongen, C. S., McCalman, J., \& Bainbridge, R. G. (2017). The implementation and evaluation of health promotion services and programs to improve cultural competency: a systematic scoping review. Frontiers in public health, 5, 24.

[25] Atasoy, H., Chen, P. Y., \& Ganju, K. (2018). The spillover effects of health IT investments on regional healthcare costs. Management Science, 64(6), 2515-2534.

[26] Butt, T., Liu, G. G., Kim, D. D., \& Neumann, P. J. (2019). Taking stock of cost-effectiveness analysis of healthcare in China. BMJ global health, 4(3), e001418.

[27] McCalman, J., Jongen, C., \& Bainbridge, R. (2017). Organizational systems' approaches to improving cultural competence in healthcare: a systematic scoping review of the literature. International journal for equity in health, 16(1), 78 .

[28] Mi, M., \& Zhang, Y. (2017). Culturally competent library services and related factors among health sciences librarians: an exploratory study. Journal of the Medical Library Association: JMLA, 105(2), 132.

[29] Lee, Y. J., \& Suh, W. S. (2016). The influence of competitive advantage on hospital performance: Focused on resource-based view (RBV). Korea Journal of Hospital Management, 21(3), 53-64.

[30] Moreno-Martínez, R., \& Martínez-Cruz, R. A. (2015). Eficiencia hospitalaria medida por el aprovechamiento del recurso cama en un hospital de segundo nivel de atención. Revista Médica del Instituto Mexicano del Seguro Social, 53(5), 552-557.

[31] Syed, S. B., Leatherman, S., Mensah-Abrampah, N., Neilson, M., \& Kelley, E. (2018). Improving the quality of health care across the health system. Bulletin of the World Health Organization, 96(12), 799 .

[32] Stefan, S. C., Popa, I., \& Dobrin, C. O. (2016). Towards a model of sustainable competitiveness of health organizations. Sustainability, 8(5), 464.

[33] Cleven, A., Mettler, T., Rohner, P., \& Winter, R. (2016). Healthcare quality innovation and performance through process orientation: Evidence from general hospitals in Switzerland. Technological Forecasting and Social Change, 113, 386-395.

[34] Pashkus, V., Pashkus, N., \& Chemlyakova, A. (2017). The problem of quality correlation and efficiency of medical services as a factor of health organizations competitiveness. In CBU International Conference Proceedings (Vol. 5, pp. 366-370).

[35] Cinaroglu, S., \& Baser, O. (2018). Understanding the relationship between effectiveness and outcome indicators to improve quality in healthcare. Total Quality Management \& Business Excellence, 29(11-12), 1294-1311.

[36] Singh, H., Dey, A. K., \& Sahay, A. (2020). Exploring sustainable competitive advantage of multispecialty hospitals in dynamic environment. Competitiveness Review: An International Business Journal.

[37] Zuriati, Z., \& Chiew, L. (2020). Relationship quality of health services with satisfaction of patients in $\mathrm{H}$. Hanafie Muara Bungo Hospital in 2019. Enfermería Clínica, 30, 168-170.

[38] Moreira, M. R., Gherman, M., \& Sousa, P. S. (2017). Does innovation influence the performance of healthcare organizations? Innovation, 19(3), 335-352. 